\title{
AGE, GROWTH, GONADOSOMATIC INDEX, AND DIET COMPOSITION OF CRIMEAN BARBEL, BARBUS TAURICUS (ACTINOPTERYGII: CYPRINIFORMES: CYPRINIDAE), IN A SMALL STREAM IN NE TURKEY
}

\author{
Rahşan E. MAZLUM* and Cemalettin ŞAHIN \\ Faculty of Fisheries, Recep Tayyip Erdoğan University, Rize, Turkey
}

\begin{abstract}
Mazlum R.E., Şahin C. 2017. Age, growth, gonadosomatic index and diet composition of Crimean barbel, Barbus tauricus (Actinopterygii: Cypriniformes: Cyprinidae), in a small Stream in NE Turkey. Acta Ichthyol. Piscat. 47 (4): 339-346.
\end{abstract}

Background. Crimean barbel, Barbus tauricus Kessler, 1877, is a riverine cyprinid fish commonly found in welloxygenated streams with gravel bottom in the Black and Azov Sea basins. Its population has plummeted in the Salgir, Chornaya, and Alma rivers (Crimea) and hence this fish has been listed as Vulnerable on the IUCN Red List. The knowledge about its age, growth, length-weight relation, spawning period, and diet composition are either scarce or not available. This paper aimed to fill the existing gaps in the knowledge by describing selected biological characteristics of B. tauricus in the Çiftekavak Stream, in the outskirts of the city of Rize, NE Turkey. Materials and methods. Crimean barbel were collected by electrofishing (60 Hz pulsed DC) from April to November 2014. The total length $(L, \mathrm{~cm})$ and weight $(W, \mathrm{~g})$ of each specimen were recorded, and sagittal otoliths, gonads, and gut contents were then recovered. The length-weight relation (LWR) was calculated by a simple power function $W=a L^{b}$. The age rings on sagittal otoliths were counted to determine fish age that was later used to analyse their growth by various growth models. The wet weight of gonads was used to calculate the gonadosomatic index (GSI). The gut contents were identified to the lowest possible taxonomic level and the contribution of a prey in the total diet composition was analysed by the occurrence frequency of prey groups $(\% \mathrm{O})$ and by numerical percentage frequency of prey groups $(\% \mathrm{~N})$.

Results. The age ranged from 0 to 4 years and more than $50 \%$ of the fish represented the 0 -year group followed by 1-year group (21.9\%) and 2-year group (13.5\%). The von Bertalanffy growth model adequately described the correlation between the fish length and the age and indicated that females grew faster than males. The LWR identified negative allometric growth patterns in males and females. The higher values of GSI from males and females were recorded from April through July, while the lowest value of GSI was observed from September through November indicating the completion of the spawning season. A total of 14 prey items (including sand grains) were identified from the guts of Crimean barbel. The main prey items were Culex sp. (larva + pupa + adult), Chironomidae, followed by Ephemeridae and Zygoptera. They constituted up to $>78 \% \mathrm{O}(>95 \% \mathrm{~N})$ of the diet.

Conclusions. The results of this study will assess the conservative regulations and policies that will eventually provide a sustainable management of Crimean barbel stocks.

Keywords: feeding ecology, reproduction Çiftekavak Stream, length-weight relation

\section{INTRODUCTION}

Crimean barbel, Barbus tauricus Kessler, 1877 are widely distributed in the Black and Azov Sea basins (Kottelat and Freyhof 2007, Çiçek et al. 2015). Those fish are commonly found in well-oxygenated streams with a gravel bottom and high current velocity (Verep et al. 2006). Their occurrence within the known range of distribution has been well documented by various authors (Dobrovolov 1996, Kotlík and Berrebi 2001, Sar1 et al. 2006). However, very little information exists on basic biological characteristics (e.g., spawning period) and feeding ecology of Crimean barbel (Kottelat and Freyhof 2007). Due to pollution, their population have plummeted in the Salgir, Chornaya, and Alma rivers (Crimea) and hence listed as a vulnerable species by the International Union for Conservation of Nature (Freyhof and Kottelat 2008).

The majority of the species of the subfamily Barbinae are bottom-feeders mainly consuming insects, including Chironomidae as the dominant prey (Collares-Pereira et al. 1996, Piria et al. 2005, Sapounidis et al. 2015). The spawning seasons of those fishes usually start in April and last until July (Herrera and Fernández-Delgado 1992, Kottelat and Freyhof 2007, Sapounidis et al. 2015). Females have a higher growth rate than males (Vitali and Braghieri 1984, De Silva et al. 1985, Herrera et al. 1988). 
In this study, the basic biological characteristics of Barbus tauricus, including sex ratios, age, growth, spawning period, and length-weight relation (LWR) were examined for the first time in the Çiftekavak Stream, in the outskirts of the city of Rize, NE Turkey. This study intends to be a complement to the results obtained for LWR by the previous authors (Tarkan et al. 2006, Şahin et al. 2007, Gaygusuz et al. 2013a, 2013b). Also, the gut contents of $B$. tauricus were analysed to determine their diet composition during spring, summer, and autumn. The impact of fish sizes on their diet composition was also noted.

\section{MATERIAL AND METHODS}

Study area. The Çiftekavak Stream is a coastal stream located about $4 \mathrm{~km}$ west of the Rize city centre. It has a total length of $6 \mathrm{~km}$ with an approximate depth of $0.4 \mathrm{~m}$, and a width of $4 \mathrm{~m}$. It flows from Tuğlalı to Çiftekavak and empties into the Black Sea. The dominant bottom substrate of the stream is gravel. During the presently reported study the water flow velocity was $1 \mathrm{~m} \cdot \mathrm{s}^{-1}$, the water temperature ranged from 15 to $22^{\circ} \mathrm{C}, \mathrm{pH}$ was 7.5-8.0, and the dissolved oxygen amounted to 8.0-10.0 $\mathrm{mg} \cdot \mathrm{L}^{-1}$. No signs of industrial or anthropogenic pollutants were found. Also, all types of fishing are banned in the area.

Fish sampling. Monthly samples of Crimean barbel, Barbus tauricus, were collected (coordinates: $\left.41^{\circ} 01^{\prime} 40^{\prime \prime} \mathrm{N}, 40^{\circ} 29^{\prime} 03^{\prime \prime} \mathrm{E}\right)$ by electrofishing ( $60 \mathrm{~Hz}$ pulsed DC) during spring, summer, and autumn seasons (from April to November 2014). No specimen could be collected in winter. Sampled fish were preserved in $10 \%$ formalin in the field.

In the laboratory, each fish was weighed (to the nearest $0.01 \mathrm{~g}$ ) and its total length was measured (to the nearest 0.1 $\mathrm{cm})$. Based on the total length, the fish were categorized into four length classes: $6.6-10.5 \mathrm{~cm}, 10.6-14.5 \mathrm{~cm}, 14.6-$ $18.5 \mathrm{~cm}$, and $>18.6 \mathrm{~cm}$. Finally, guts, gonads, and sagittal otoliths were recovered. The gut contents were promptly collected on Petri dishes and were identified to the lowest possible taxonomic level while the wet weight of the gonads was determined to the nearest $0.01 \mathrm{~g}$. Furthermore, the sex of the collected specimens was determined by dissection of gonads.

Field samplings performed in this study were authorized by Ministry of Food, Agriculture and Livestock, General Directorate of Agricultural Research and Policies, Turkey.

Age determination. The age rings on whole sagittal otoliths were counted using a Nikon SMZ1000 stereomicroscope coupled to a Nikon DSFI1 digital camera at a magnification between $\times 0.8$ and $\times 8.0$. In order to make the growth rings clearly visible, each otolith was gently sanded using sandpaper.

Growth estimation. Several growth models were applied to the size-at-age data of Barbus tauricus to analysis their growth:

- [1] von Bertalanffy (1938) model

- [2] Gompertz (1825) model

- [3] Richards (1959) curve model
- [4] Exponential model (Schmalhausen 1926 as cited in Ricker 1979)

The respective formulas are given below:

$$
\begin{gathered}
L=L_{\infty}\left(1-e^{-K\left(t-t_{0}\right)}\right) \\
\log L=\log L_{\infty} e^{-K(t-1)} \\
L=\frac{L_{\infty}}{1+e^{-K(t-1)}} \\
L=L_{\infty}-\left(L_{\infty}-\beta\right) e^{(-(k t))}
\end{gathered}
$$

where $L$ is the fish total length [cm] at the time $t$ (age), $L_{\infty}$ is the upper asymptotic total length [cm], $K$ is the growth rate coefficient [year $\left.{ }^{-1}\right], t_{0}$ and $\beta$ is the hypothetical age. These parameters were estimated using PRIMER 6.0 (Plymouth Routines In Multivariate Ecological Research) software. The best fit model to the size-at-age data was determined using Akaike Information Criterion (AIC) results (Akaike 1974) and the one provided the lowest AIC was chosen as an adequate growth model. Furthermore, the growth performance index $\left(\varphi^{\prime}\right)$ was calculated as indices of growth performance by following the formula using the values of $K$ and $L_{\infty}$ (Pauly and Munro 1984):

$$
\varphi^{\prime}=\log (K)+2 \log \left(L_{\infty}\right)
$$

Length-weight relation. The LWR of Barbus tauricus was determined by following formula:

$$
W=a L^{b}=>\log W=\log a+b \cdot \log L
$$

where $W$ is the body weight [g], $L$ is the total length [cm], $a$ is the intercept, and $b$ is the slope.

The statistical deviation of estimated $b$ from the isometric value (3.0) was tested by $t$-test (Pauly 1984).

Gonadosomatic index. The gonadosomatic index GSI were determined as:

$$
\mathrm{GSI}=100 \cdot W_{\mathrm{g}} \cdot W_{\mathrm{f}}^{-1}
$$

where $W_{\mathrm{g}}$ is the gonad weight [g], $W_{\mathrm{f}}$ is fish body weight [g].

Gut fullness. The gut fullness (ca. percentage fullness) was determined visually for each specimen according to Kitsos et al. (2008). The fullness scale ranged from $0 \%$ to $100 \%$ with empty as empty $(0 \%)$, moderately full $(25 \%)$, half full (50\%), quite full (75\%), and very full (100\%).

Qualitative dietary analysis. The contribution of each prey item to the total gut contents was analysed by the occurrence frequency of prey groups $(\% \mathrm{O})$ and by numerical percentage frequency of prey groups (see reviews by Hyslop 1980, Cortés 1997). The abovementioned indices were calculated as:

$$
\% \mathrm{O}=\frac{n}{N_{\mathrm{s}}} \cdot 100
$$




$$
\% \mathrm{~N}=\frac{n^{i}}{N_{\mathrm{p}}} \cdot 100
$$

where $n$ is the number of guts of a particular prey type, $N_{\mathrm{s}}$ is the total number of guts containing prey, $n^{i}$ is the total number of prey in a food group, and $N_{\mathrm{p}}$ is the total number of all prey groups.

Dietary variation. The similarities in diet composition between different length classes during different seasons were estimated by dendrogram using the PRIMER 6.0 software package (Clarke and Warwick 2001).

\section{RESULTS}

Length frequency distribution and sex ratio. A total of 360 Crimean barbel were collected throughout the study whose sizes (total length) ranged between 5.0 and $24.7 \mathrm{~cm}$. Females and males ranged in total length between 7.8 and $24.7 \mathrm{~cm}(n=90)$ and $6.8-18.2 \mathrm{~cm}(n=149)$, respectively. Mean total lengths of females were significantly greater than males ( $t$-test, $P<0.001)$. The total length of juvenile ranged between 5 and $10.9 \mathrm{~cm}(n=121)$. The length frequency distributions of males and females also differed significantly (Kolmogorov-Smirnov two-sample test: $d$ $=0.4635, P<0.001)$. The dominant size classes in the length frequency distribution for males were 12 and 14 while the dominant size class for females was $13 \mathrm{~cm}$. Among juveniles, the dominant size classes were 8, 9, and $10 \mathrm{~cm}$ (Fig. 1). Sex ratios for the population of Crimean barbel in the Çiftekavak Stream indicate a dominance of males with (female $\div$ male) $0.60 \div 1$ but it did not deviate significantly from $1 \div 1\left(\chi^{2}=0.263 ; P=0.608\right)$.

Age and growth. Otoliths from 274 individuals were extracted and read successfully (Table 1). The majority of the individuals represented the 0 -year age group (53.7\%) and half of them were of juveniles. The estimation of growth parameters included all age groups. Based on AIC values, the correlation between the total length and age of $B$. tauricus was adequately described by the von Bertalanffy model. The faster growth rates were also indicated by the growth performance index that produced a higher value of $\varphi^{\prime}$ for female (Table 2).

Length-weight relation. The LWR was determined for male and female separately and for all individuals that representing both sexes and the juveniles (Table 3). The estimated values of allometric coefficient indicated isometric allometry of growth of females and males. A

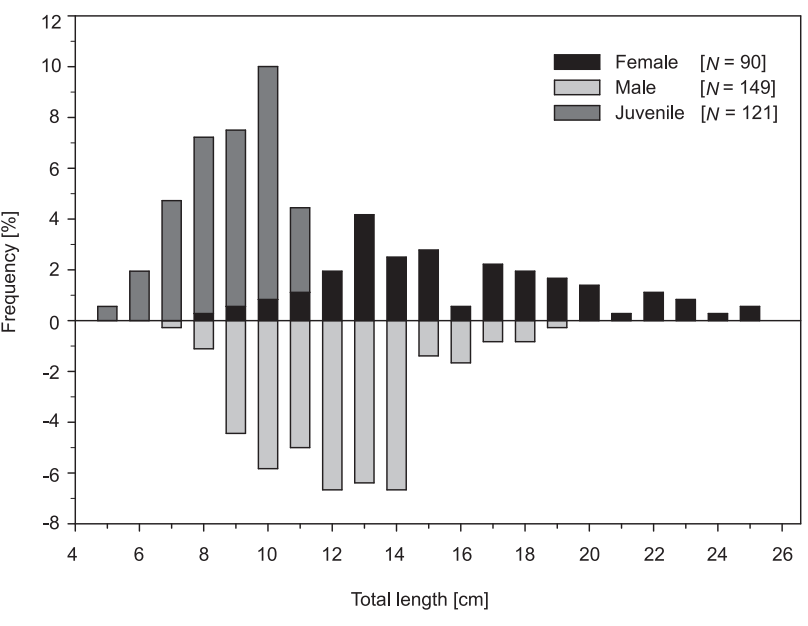

Fig. 1. Total length frequency distribution of females, males, and juvenile Crimean barbel, Barbus tauricus, sampled during spring, summer, and autumn from the Çiftekavak Stream, in the outskirts of the city of Rize, NE Turkey

Table 1

Principal biometric parameters of Crimean barbel, Barbus tauricus, in the Çiftekavak Stream, in the outskirts of the city of Rize, NE Turkey

\begin{tabular}{|c|c|c|c|c|c|c|}
\hline \multirow{2}{*}{ Age class [year] } & \multirow{2}{*}{ Sex } & \multicolumn{2}{|c|}{ Total length $[\mathrm{cm}]$} & \multicolumn{2}{|c|}{ Body weight $[\mathrm{g}]$} & \multirow{2}{*}{$n$} \\
\hline & & Mean \pm SE & Range & Mean \pm SE & Range & \\
\hline \multirow[t]{4}{*}{0} & \% & $9.60 \pm 0.09$ & $8.8-10.5$ & $8.79 \pm 0.28$ & $6.66-11.94$ & 24 \\
\hline & $\sigma^{x}$ & $9.40 \pm 0.09$ & $8.2-11.2$ & $8.95 \pm 0.27$ & $5.50-14.61$ & 52 \\
\hline & $\mathrm{J}$ & $7.30 \pm 0.13$ & $5.0-8.90$ & $4.39 \pm 0.22$ & $1.17-8.64$ & 71 \\
\hline & All & $8.40 \pm 0.12$ & $5.0-11.2$ & $6.72 \pm 0.24$ & $1.17-14.61$ & 147 \\
\hline \multirow[t]{3}{*}{1} & 운 & $12.92 \pm 0.54$ & $10.3-18.6$ & $25.38 \pm 4.18$ & $8.82-70.16$ & 21 \\
\hline & $0^{\pi}$ & $11.92 \pm 0.29$ & $10.1-18.2$ & $18.61 \pm 1.92$ & $8.81-68.35$ & 39 \\
\hline & All & $12.26 \pm 0.27$ & $10.1-18.6$ & $20.98 \pm 1.95$ & $8.81-70.16$ & 60 \\
\hline \multirow[t]{3}{*}{2} & 운 & $16.73 \pm 0.97$ & $10.1-22.4$ & $53.20 \pm 8.00$ & $9.74-97.43$ & 15 \\
\hline & $\sigma^{x}$ & $13.66 \pm 0.28$ & $11.3-17.0$ & $26.26 \pm 2.14$ & $13.65-59.20$ & 22 \\
\hline & All & $14.91 \pm 0.49$ & $10.1-22.4$ & $37.18 \pm 4.07$ & $9.74-97.43$ & 37 \\
\hline \multirow[t]{3}{*}{3} & ९ & $18.12 \pm 0.61$ & $14.5-22.8$ & $64.96 \pm 6.40$ & $30.91-118.8$ & 17 \\
\hline & $\sigma^{x}$ & $15.10 \pm 0.71$ & $12.6-17.5$ & $36.83 \pm 6.71$ & $18.02-69.35$ & 7 \\
\hline & All & $17.24 \pm 0.55$ & $12.6-22.8$ & $56.76 \pm 5.54$ & $18.02-118.8$ & 24 \\
\hline \multirow[t]{3}{*}{4} & q & $20.65 \pm 2.31$ & $14.6-24.7$ & $97.77 \pm 28.54$ & $33.39-151.8$ & 4 \\
\hline & $\sigma^{x}$ & $15.50 \pm 0.00$ & $15.5-15.5$ & $34.59 \pm 0.36$ & $34.24-34.95$ & 2 \\
\hline & All & $18.93 \pm 1.82$ & $14.6-24.7$ & $76.71 \pm 22.43$ & $33.39-151.8$ & 6 \\
\hline Overall & & $11.16 \pm 0.23$ & $5.0-24.7$ & $19.87 \pm 1.45$ & $1.17-151.77$ & 274 \\
\hline
\end{tabular}

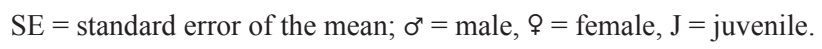


slightly positive allometry pattern, however, was obtained from combined data.

Gonadosomatic index. The reproductive period was determined using the GSI values (68 females and 140 males). The highest values of GSI were found during April followed by the same pattern (in subsequent months). The GSI values of females were also observed to be higher from April through July with the highest value during June (Fig. 2). The lowest GSI values were found during September, October, and November. During these three months, the GSI values were found statistically similar for both males (ANOVA, $F_{2,23}=0.382 ; P=0.687$ ) and females $\left(F_{2,5}=0.189 ; P=0.833\right)$. These findings indicated the completion of spawning season before September.

Overall diet composition. A total of 213 alimentary tracts from fish ranging from 6.8 to $24.7 \mathrm{~cm}$ of total length $(12.46 \pm 0.17 \mathrm{~cm})$ were examined for diet composition. It turned out that $7 \%$ of guts were empty, $62.9 \%$ were moderately full, and $>16.9 \%$ were half full, $9.95 \%$ were quite full, and 3.3\% were very full (Fig. 3).

The diets of Crimean barbel included a total 14 prey types (including sand grains), of which seven belonged to order Diptera. The contribution of each prey type during different seasons as well as in overall diet compositions are summarized in Table 4. Diptera made up $68.31 \% \mathrm{O}$ $(80.31 \% \mathrm{~N})$ of the overall diet. The four most predominant prey items were Chironomidae, Culex sp. (larva + pupa + adult), followed by Ephemeridae and Zygoptera.

Diet of Crimean barbel of different sizes in relation to season. The main prey group of different fish sizes remained Diptera constituting to $>66 \% \mathrm{O}(>65 \% \mathrm{~N})$ of the total diet composition of all length classes (excluding 6.6$10.5 \mathrm{~cm}$ length class) during different seasons (Table 4). The diet composition of $6.6-10.5 \mathrm{~cm}$ length class contained $58 \% \mathrm{O}(55 \% \mathrm{~N})$ of Diptera. Similar to overall diet, the diets of all length classes (excluding 6.6-10.5 cm length class in spring) were largely made up by Chironomidae, Culex sp. (larva + pupa + adult), Ephemeridae, and Zygoptera $(>83 \% \mathrm{O},>87 \% \mathrm{~N})$. Moreover, the most dominant prey item was Culex sp. (larva + pupa + adult) in spring and summer seasons while during autumn it was replaced by Chironomidae. The higher amount of Nematoda gen. sp. $(6 \% \mathrm{~N}, 17 \% \mathrm{O})$ and plant detritus $(17 \% \mathrm{O})$ were recovered from the $6.6-10.5 \mathrm{~cm}$ length class in autumn.

Similarities in the diet composition. The dendrogram generated based on the results obtained showed diets of all different sizes of Barbus tauricus revealed $>85 \%$ similarity in summer. Spring diet of 6.6-10.5, 10.6-14.5,

Table 2

The growth parameters for Crimean barbel, Barbus tauricus, derived from different growth models are presented with growth performance index

\begin{tabular}{|c|c|c|c|c|c|c|c|c|}
\hline & \multirow{2}{*}{ Growth model } & \multicolumn{7}{|c|}{ Growth parameter } \\
\hline & & $L_{\infty}[\mathrm{cm}]$ & $K\left[\right.$ year $\left.^{-1}\right]$ & $t_{0}[$ year $]$ & $I$ [year] & $\beta[\mathrm{cm}]$ & AIC & $\varphi^{\prime}$ \\
\hline \multirow{4}{*}{ 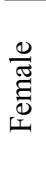 } & VBGF & 22.62 & 0.4266 & -1.005 & & & 995.91 & 5.386 \\
\hline & Exponential & 22.62 & 0.4266 & & & 7.89 & 995.91 & 5.386 \\
\hline & Gompertz 1825 & 20.53 & 0.7057 & & -0.0401 & & 997.31 & 5.695 \\
\hline & Richards 1959 & 23.49 & 0.3506 & & -1.5211 & & 997.89 & 5.265 \\
\hline \multirow{4}{*}{$\frac{\frac{0}{\pi}}{\Sigma}$} & VBGF & 16.14 & 0.6131 & -1.17 & & & 1174.36 & 5.073 \\
\hline & Exponential & 16.14 & 0.6132 & & & 8.24 & 1174.36 & 5.074 \\
\hline & Gompertz 1825 & 15.56 & 0.8419 & & -0.5082 & & 1175.83 & 5.317 \\
\hline & Richards 1959 & 16.58 & 0.4728 & & -1.8974 & 8.23 & 1176.24 & 4.867 \\
\hline
\end{tabular}

$L_{\infty}=$ the upper asymptote, $K=$ the growth rate, $t_{0}=$ the time when $L=0, I=$ the age at the inflection point, $\beta=$ the size at time zero, $\varphi^{\prime}=$ growth performance index, AIC $=$ Akaike Information Criterion, $\mathrm{VBGF}=$ von Bertalanffy growth function.

Table 3

Total length and parameters of the length-weight relation (LWR) for Crimean barbel, Barbus tauricus, from in the Çiftekavak Stream and from other locations in Turkey

\begin{tabular}{|c|c|c|c|c|c|c|c|c|}
\hline \multirow{2}{*}{ Sex } & \multirow{2}{*}{$n$} & \multirow{2}{*}{ TL range $[\mathrm{cm}]$} & \multicolumn{4}{|c|}{ LWR Parameter } & \multirow{2}{*}{$P$} & \multirow{2}{*}{ Reference } \\
\hline & & & $a$ & $b$ & $\operatorname{SE}(b)$ & $r^{2}$ & & \\
\hline $\mathrm{B}$ & 12 & $4.9-22.6$ & 0.010 & 3.050 & 0.012 & 0.989 & - & Tarkan et al. 2006 \\
\hline B & 304 & $5.0-23.0$ & 0.011 & 2.983 & - & 0.993 & - & Şahin et al. 2007 \\
\hline B & 123 & $6.8-40.0$ & 0.007 & 3.060 & 0.048 & 0.972 & - & Gaygusuz et al. 2013a \\
\hline B & 65 & $9.2-40.0$ & 0.007 & 3.089 & - & - & ns & Gaygusuz et al. $2013 b$ \\
\hline$\sigma^{2}$ & 149 & $6.8-18.2$ & 0.016 & 2.849 & 0.051 & 0.96 & ns & This study \\
\hline & 90 & $7.8-24.7$ & 0.016 & 2.875 & 0.054 & 0.97 & ns & \\
\hline B & 360 & $5.0-24.7$ & 0.010 & 3.029 & 0.022 & $0.98 ?$ & $<0.05$ & \\
\hline
\end{tabular}

$\mathrm{TL}=$ total length; $a=$ constant (intercept), $b=$ constant (slope of regression line), $\mathrm{SE}=$ standard error; $\sigma^{n}=$ male,,$q=$ female, $\mathrm{B}=$ both sexes including juveniles. 


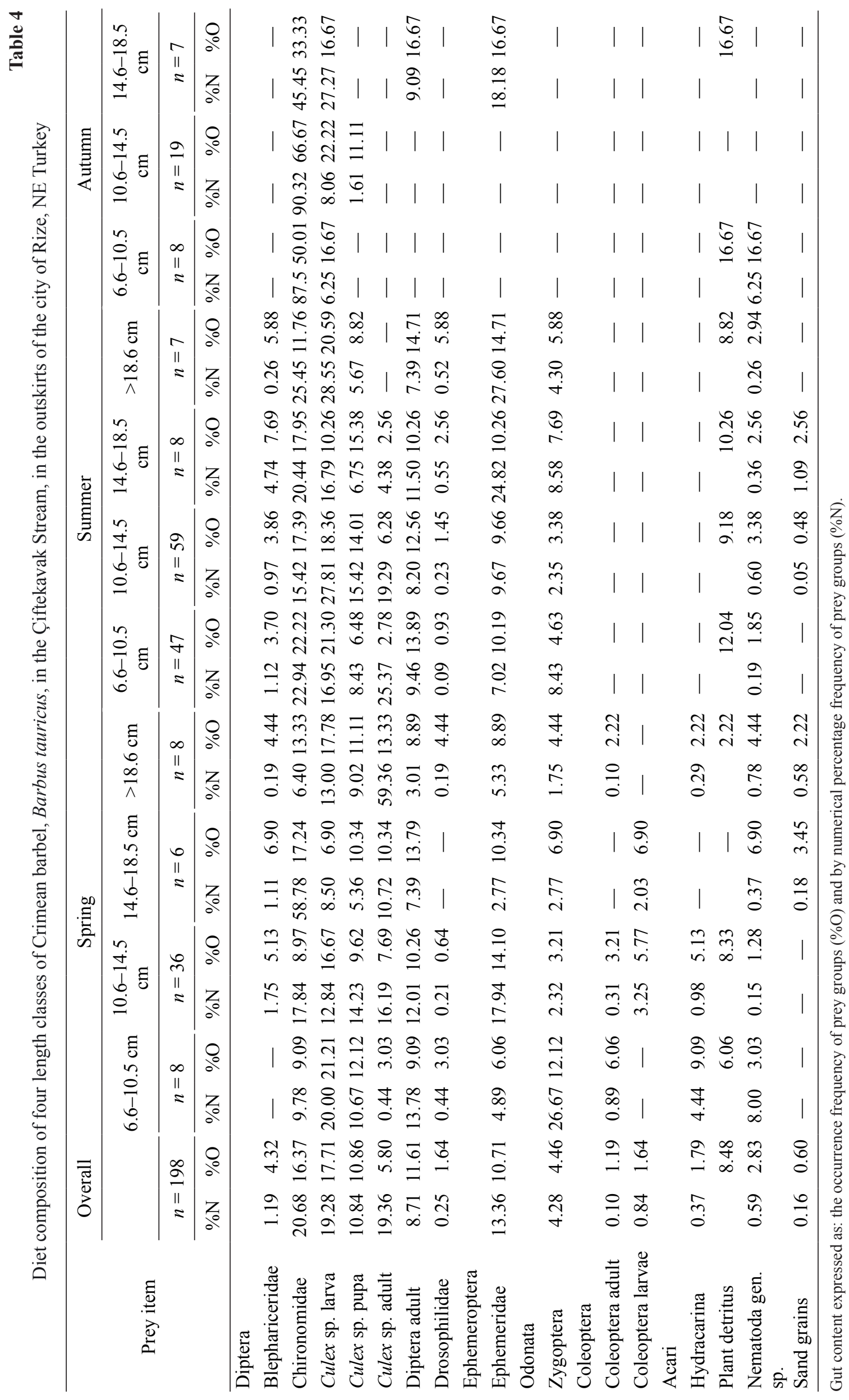




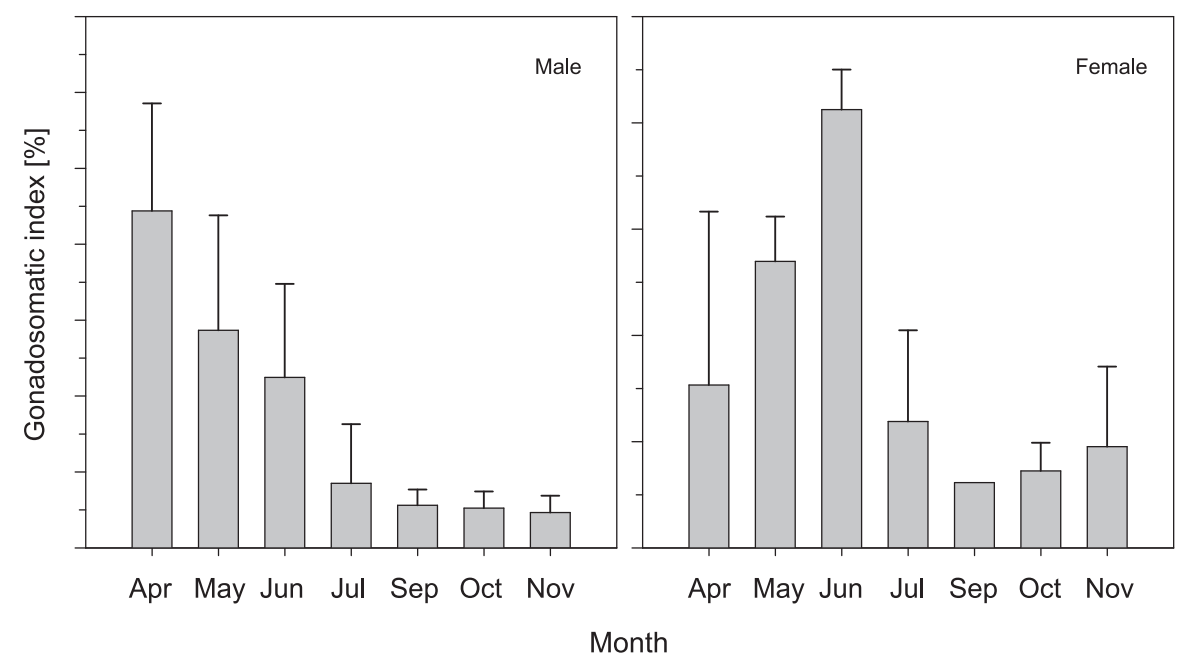

Fig. 2. Monthly gonadosomatic index values (Mean $\pm \mathrm{SD}$ ) of males and females of Crimean barbel, Barbus tauricus, caught from Çiftekavak Stream, in the outskirts of the city of Rize, NE Turkey

and $>18.6 \mathrm{~cm}$ length classes showed $>80 \%$ similarity. On the other hand, the diets of different sizes B. tauricus during autumn had relatively lower similarities and the diet of 6.6-10.5 and 14.5-18.5 cm length classes showed $>67 \%$ similarity. The spring and summer groups separated from the autumn with $48.5 \%$ dissimilarity (Fig. 4).

\section{DISCUSSION}

Sex ratio and growth rates. In this study, sex ratios of Barbus tauricus did not deviate from $1 \div 1$ which were in line with the results of other studies on Barbinae, such as Luciobarbus sclateri (Günther, 1868); Carasobarbus luteus (Heckel, 1843); and Barbus balcanicus Kotlík, Tsigenopoulos, Ráb et Berrebi, 2002 (see Herrera et al. 1988, Al Hazzaa 2005, Žutinić et al. 2014). Whereas a trend of more males than females was reported for L. sclateri (1.3 $\div 1$, Guadalquivir River basin), Barbus cyclolepis Heckel, 1837 (1.28 $\div$, in Macedonia), and B. strumicae $(1.93 \div 1$, Nestos River) (Harrera and Fernández-Delgado 1992, Vasiliou and Economidis 2005, Sapounidis et al. 2015). The dominance of females over males was reported for Barbus plebejus Bonaparte, 1839 with $3.02 \div 1.77$ sex ratio (Vitali and Braghieri 1984).

The female Barbus tauricus had higher growth rate than male that is in accordance with the growth rates determined for other Barbinae species such as B. plebejus (see Vitali and Braghieri 1984); Puntius vittatus Day, 1865; Puntius bimaculatus (Bleeker 1863); Pethia cumingii (Günther, 1868) (see De Silva et al. 1985); and Luciobarbus sclateri (Günther, 1868) (see Herrera et al. 1988). While both male and female of Barbus strumicae Karaman, 1955 showed equivalent growth rates with a growth performance index of 3.884 (Sapounidis et al. 2015).

Length-weight relation. The LWR of Barbus tauricus (all 360 specimens) evinced that they grow in slightly positive allometry pattern which was consistent with previous studies from Ömerli Dam Lake (Tarkan et al. 2006), Yeşildere Stream (Şahin et al. 2007), and Emet Stream, Porsuk Stream, and the Sakarya River at Sakaryabaş1 (Gaygusuz et al. 2013a, 2013b). In this study,

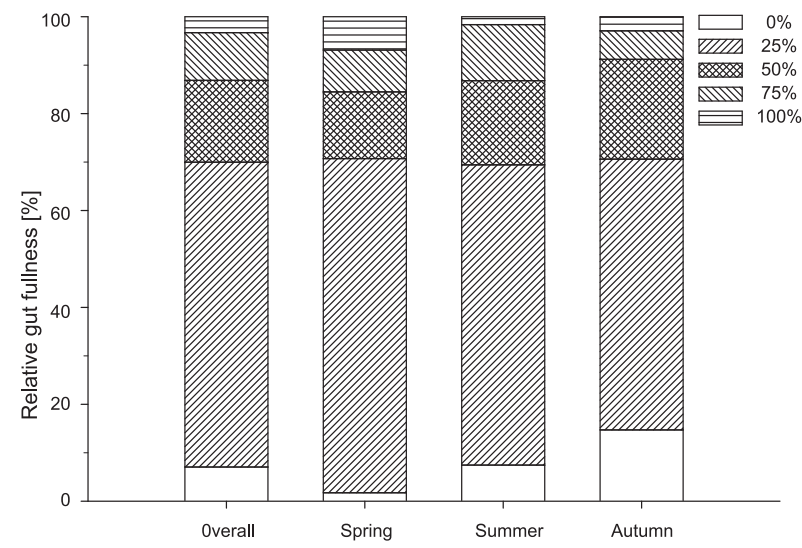

Fig. 3. Seasonal gut fullness ratio of Crimean barbel, Barbus tauricus, sampled from the Çiftekavak Stream, in the outskirts of the city of Rize, NE Turkey

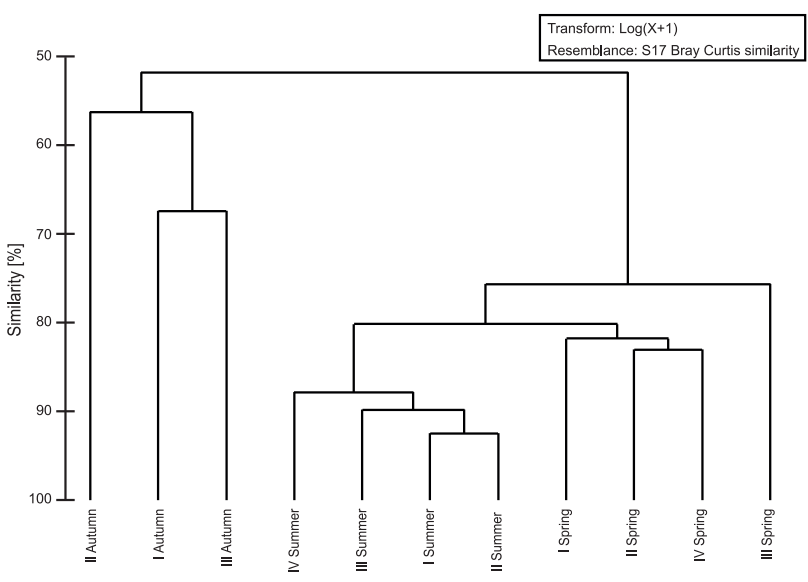

Fig. 4. Dendrogram (based on percentage of prey groups occurrence frequency $\% \mathrm{O}$ ) depicting the seasonal similarities in the diet composition of four different length classes (I: $6.6-10.5 \mathrm{~cm}$, II: $10.6-14.5 \mathrm{~cm}$, III: $14.6-18.5 \mathrm{~cm}$, and IV: $>18.6 \mathrm{~cm}$ ) of Crimean barbel, Barbus tauricus, from the Ciftekavak Stream, in the outskirts of the city of Rize, NE Turkey 
the LWR of males and females (calculated separately) showed that they grow following isometric allometry growth pattern (Table 3). In previous studies, the LWR of males and females were not reported separately, therefore estimating the length or weight of B. tauricus using the LWR parameters obtained from combined data (males, females, and juveniles) would result in erroneous estimation for male and female.

Spawning period. The spawning season of Barbus tauricus in the Çiftekavak Stream started in April and lasted until July, which was in line with the results of Herrera and Fernández-Delgado (1992) on Luciobarbus sclateri, results of Vasiliou and Economidis (2005) on Barbus peloponnesius Valenciennes, 1842 and Barbus cyclolepis, and results of Sapounidis et al. (2015) on Barbus strumicae. Furthermore, according to Kottelat and Freyhof (2007) majority of Barbus spp. spawn in May-July.

Diet composition. Barbus tauricus exclusively feed on insects and the presence of plant detritus and sand grains (also Nematoda gen. sp.) in their gut contents evinced their feeding habits to be an omni-insectivorous bottom-feeder. The contribution of Diptera to the diet of $B$. tauricus as the first most frequent prey group along with the presence of plant detritus were in accordance with the results reported from previous studies on the feeding ecology of Luciobarbus bocagei (Steindachner, 1864) (see Magalhães 1993, Collares-Pereira et al. 1996), Barbus barbus (Linnaeus, 1758) (see Piria et al. 2005), Barbus cyclolepis (see Rozdina et al. 2008) and Barbus strumicae (see Sapounidis et al. 2015). Furthermore, Collares-Pereira et al. (1996) and Sapounidis et al. (2015) also reported the presence of sand grains in the gut contents of B. bocagei and B. strumicae. The results of the presently reported study stand in contrast to earlier work regarding the first most frequent prey item in the diets. The diets of aforementioned species were dominant by Chironomidae however the dominant prey item in the gut contents (overall diet composition) of B. tauricus was Culex sp. (larva + pupa + adult) or Chironomidae (Table 4). Based on seasonal data, during spring and summer, the diets were dominant by Culex sp. while in autumn the Chironomidae became the first most frequent prey items in the diet of B. tauricus. According to by Kottelat and Freyhof (2007) Crimean barbel move to deeper places with less current and stop feeding during winter. The presence of nematodes in the gut contents of Barbus sp. were also reported by Admassu and Dadebo (1997) from Lake Awassa, Ethiopia.

\section{REFERENCES}

Admassu D., Dadebo E. 1997. Diet composition, lengthweight relationship and condition factor of Barbus species (Rüppell, 1836) (Pisces: Cyprinidae) in Lake Awassa, Ethiopia. SINET: Ethiopian Journal of Science 20 (1): 13-30.

Akaike H. 1974. A new look at the statistical model identification. IEEE Transactions on Automatic Control 19 (6): 716-723.
DOI: 10.1109/TAC.1974.1100705

Al Hazzaa R. 2005. Some biological aspects of the Himri barbel, Barbus luteus, in the intermediate reaches of the Euphrates River. Turkish Journal of Zoology 29 (4): 311-315.

Çiçek E., Birecikligil S.S., Fricke R. 2015. Freshwater fishes of Turkey: A revised and updated annotated checklist. Biharean Biologists 9 (2): 141-157.

Clarke K.R., Warwick R.M. 2001. Change in marine communities: An approach to statistical analysis and interpretation. 2nd edn. PRIMER-E, Plymouth, UK.

Collares-Pereira M., Martins M., Pires A., Geraldes A.M., Coelho M. 1996. Feeding behaviour of Barbus bocagei assessed under a spatio-temporal approach. Folia Zoologica 45 (1): 65-76.

Cortés E. 1997. A critical review of methods of studying fish feeding based on analysis of stomach contents: Application to elasmobranch fishes. Canadian Journal of Fisheries and Aquatic Sciences 54 (3): 726-738. DOI: $10.1139 /$ cjfas-54-3-726

De Silva S.S., Schut J., Kortmulder K. 1985. Reproductive biology of six Barbus species indigenous to Sri Lanka. Environmental Biology of Fishes 12 (3): 201-218. DOI: $10.1007 / \mathrm{BF} 00005151$

Dobrovolov I. 1996. Biochemical genetic characteristics of barbel (Barbus Cuvier genus) from Bulgarian rivers. Folia Zoologica 45 (Suppl. 1): 59-65.

Freyhof J., Kottelat M. 2008. Barbus tauricus. The IUCN Red List of Threatened Species 2008: e.T135540A4141202. [Downloaded on 24 November 2017.] DOI: 10.2305/IUCN.UK.2008.RLTS. T135540A4141202.en

Gaygusuz Ö., Aydın H., Emiroğlu Ö., Top N., Dorak Z., Gaygusuz Ç.G., Başkurt S., Tarkan A.S. 2013a. Length-weight relationships of freshwater fishes from the western part of Anatolia, Turkey. Journal of Applied Ichthyology 29 (1): 285-287.

DOI: $10.1111 /$ jai.12015

Gaygusuz Ö., Emiroğlu Ö., Tarkan A.S., Aydın H., Top N., Dorak Z., Karakuş U., Başkurt S. 2013b. Assessing the potential impact of nonnative fish on native fish by relative condition. Turkish Journal of Zoology 37 (1): 84-91. DOI: $10.3906 /$ zoo-1203-15

Gompertz B. 1825. [XXIV.] On the nature of the function expressive of the law of human mortality, and on a new mode of determining the value of life contingencies. Philosophical Transactions of the Royal Society of London 115: 513-585.

Harrera M., Fernández-Delgado C. 1992. The lifehistory patterns of Barbus bocagei sclateri (Günther, 1868) in a tributary stream of the Guadalquivir River basin, southern Spain. Ecology of Freshwater Fish 1 (1): 42-51.

DOI: 10.1111/j.1600-0633.1992.tb00006.x

Herrera M., Hernando J., Fernandez-Delgado C., Bellido M. 1988. Age, growth and reproduction of the barbel, Barbus sclateri (Günther, 1868), in a first-order 
stream in southern Spain. Journal of Fish Biology 33 (3): $371-381$.

DOI: $10.1111 / \mathrm{j} .1095-8649.1988 . t b 05479 . x$

Hyslop E. 1980. Stomach contents analysis - a review of methods and their application. Journal of Fish Biology 17 (4): 411-429.

DOI: $10.1111 /$ j.1095-8649.1980.tb02775.x

Kitsos M.S., Tzomos T., Anagnostopoulou L., Koukouras A. 2008. Diet composition of the seahorses, Hippocampus guttulatus Cuvier, 1829 and Hippocampus hippocampus (L., 1758) (Teleostei, Syngnathidae) in the Aegean Sea. Journal of Fish Biology 72 (6): 1259-1267.

DOI: 10.1111/j.1095-8649.2007.01789.x

Kotlík P., Berrebi P. 2001. Phylogeography of the barbel (Barbus barbus) assessed by mitochondrial DNA variation. Molecular Ecology 10 (9): 2177-2185. DOI: 10.1046/j.0962-1083.2001.01344.x

Kottelat M., Freyhof J. 2007. Handbook of European freshwater fishes. Kottlelat, Cornol, Switzerland and Freyhof, Berlin, Germany.

Magalhães M. 1993. Feeding of an Iberian stream cyprinid assemblage: Seasonality of resource use in a highly variable environment. Oecologia 96 (2): 253260 .

DOI: $10.1007 / \mathrm{BF} 00317739$

Pauly D. 1984. Fish population dynamics in tropical waters: A manual for use with programmable calculators. ICLARM Studies and Reviews Vol. 8.

Pauly D., Munro J. 1984. Once more on the comparison of growth in fish and invertebrates. Fishbyte 2 (1): 21.

Piria M., Treer T., Aničić I., Safner R., Odak T. 2005. The natural diet of five cyprinid fish species. Agriculturae Conspectus Scientificus 70 (1): 21-28.

Richards F. 1959. A flexible growth function for empirical use. Journal of Experimental Botany 10 (2): 290-301. DOI: $10.1093 / \mathrm{jxb} / 10.2 .290$

Ricker W.E. 1979. [11] Growth rates and models. Pp. 678-744. In: Hoar W.S., Randall D.J., Brett J.R. (eds.) Fish physiology. Vol. 8. Bioenergetics and growth. Academic Press, New York, NY, USA. DOI: $10.1016 / \mathrm{S} 1546-5098(08) 60034-5$

Rozdina D., Raikova-Petrova G., Marinova R., Uzunova E. 2008. Food spectrum and feeding of Barbus cyclolepis Heckel from the middle stream of Maritza River (Bulgaria). Bulgarian Journal of Agricultural Science 14 (2): 209-213.
Şahin C., Imamoğlu H.O., Turan D., Verep B., Taşkin V. 2007. A preliminary study on growth parameters and mortality rates of the barbel (Barbus tauricus escherichi Steindachner, 1897) in Yeşildere Stream, Rize, Turkey. Turkish Journal of Zoology 31 (4): 295 300.

Sapounidis A.S., Koutrakis E.T., Leonardos I.D. 2015. Life history traits, growth and feeding ecology of a native species (Barbus strumicae Karaman, 1955) in Nestos River, a flow regulated river in northern Greece. North-Western Journal of Zoology 11 (2): 331-341.

Sarı H.M., Balık S., Ustaoğlu M.R., Ilhan A. 2006. Distribution and ecology of freshwater ichthyofauna of the Biga Peninsula, north-western Anatolia, Turkey. Turkish Journal of Zoology 30 (1): 35-45.

Schmalhausen I. 1926. Studien über Wachstum und Differenzierung. III. Die embryonale Wachstumskurve des Hühnchens. Wilhelm Roux' Archiv für Entwicklungsmechanik der Organismen 108 (2): 322387.

DOI: $10.1007 / \mathrm{BF} 02080840$

Tarkan A., Gaygusuz Ö., Acıpınar H., Gürsoy Ç., Özuluğ M. 2006. Length-weight relationship of fishes from the Marmara region (NW-Turkey). Journal of Applied Ichthyology 22 (4): 271-273. DOI: $10.1111 /$ j.1439-0426.2006.00711.x

Vasiliou A., Economidis P.S. 2005. On the life-history of Barbus peloponnesius and Barbus cyclolepis in Macedonia, Greece. Folia Zoologica 54 (3): 316-336.

Verep B., Turan D., Kováč V. 2006. Preliminary results on morphometry of barbel (Barbus tauricus Kessler, 1877 ) in the streams of Rize and Artvin provinces (Turkey). Turkish Journal of Fisheries and Aquatic Sciences 6 (1): 17-21.

Vitali R., Braghieri L. 1984. Population dynamics of Barbus barbus plebejus (Valenciennes) and Leuciscus cephalus cabeda (Risso) in the middle River Po (Italy). Hydrobiologia 109 (2): 105-124.

DOI: $10.1007 / \mathrm{BF} 00011570$

von Bertalanffy L. 1938. A quantitative theory of organic growth (inquiries on growth laws. II). Human Biology 10 (2): 181-213.

Žutinić P., Jelić D., Jelić M., Buj I. 2014. A contribution to understanding the ecology of the large spot barbelsexual dimorphism, growth and population structure of Barbus balcanicus (Actinopterygii; Cyprinidae) in Central Croatia. North-Western Journal of Zoology 10 (1): 158-166. 